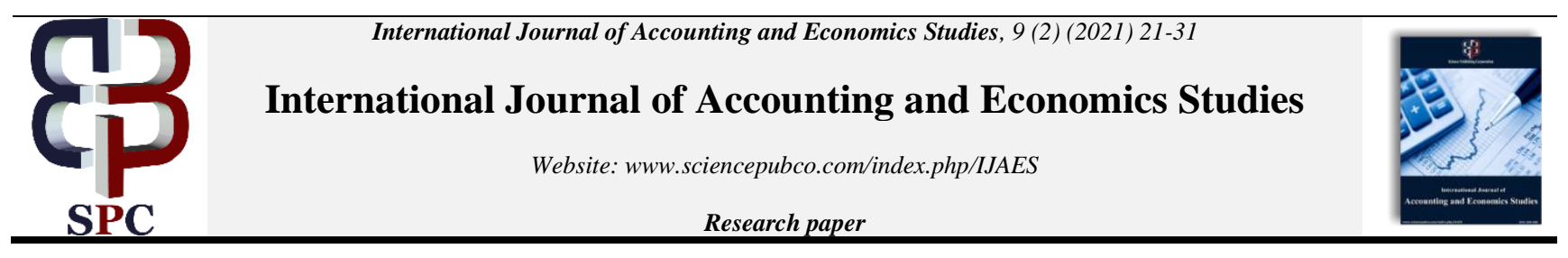

\title{
How the inclusion of thermodynamic principles recovers economic sciences
}

\author{
Mieczyslaw Dobija ${ }^{1}$, Jurij Renkas ${ }^{2 *}$ \\ ${ }^{1}$ Department of Accountancy, Cracow University of Economics, Rakowicka St., 27, 31-425, Cracow, Poland \\ Nr ORCID: 0000000306702313 \\ ${ }^{2}$ Department of Accountancy, Cracow University of Economics, Rakowicka St., 27, 31-425, Cracow, Poland \\ Nr ORCID: 0000-0001-7139-5458 \\ *Corresponding author E-mail: renkasj@uek.krakow.pl
}

\begin{abstract}
So far, economics does not have a coherent theory. This condition is a consequence of the ambiguity of basic categories such as capital, labor, money, and consumption. In the traditional narrative, these categories do not have a strict scientific meaning. This situation is positively changed by the inclusion of the fundamental principles of thermodynamics, especially the famous second principle. This is the main hypothesis argued in the body of the article. The consistent use of thermodynamics made it possible to reinterpret the system of fundamental concepts, as well as to solve cognitive problems in the field of capital and labor theory and sources of profit. The results of the presented empirical research indicate the consistency of the modified economic theory.
\end{abstract}

Keywords: Thermodynamic; Economic Sciences; Economic Constant; Capital; Fair Remuneration.

\section{Introduction}

Thermodynamics originated as the science of the motive power of fire. It developed in the nineteenth century about a century after the introduction of the first steam propulsion systems and, according to the authors [Bejan, Tsatsaronis, 2021], is a pillar of physics, chemistry, life sciences, and engineering sciences. Thermodynamics is also present in cosmology [Barbour, 2020, pp. 46-48], psychology [Tobby, Cosmides, Barrett, 2003], character studies [Mazur, 1976] accounting theory [Dobija, Kurek, 2013], [Dobija, Renkas, 2020], and in economics it has been applied to issues of human capital measurement [Dobija, 2004, 2005]. As it is known, thermodynamics has as its basis fundamental principles, without which it is impossible to fully understand many theoretical issues. This state of affairs is recognized in economic sciences when interpreting such important categories and issues as capital, labor, value, money, [Dobija, Renkas, 2021].

Thermodynamics is an all-encompassing science whose laws govern life, and in the case of human beings also shape personal human capital, i.e., the ability to perform work. Thus, work being a transfer of human capital has its origin in the existence of this capital and sustaining its high exergy [Pudlik, pp. 188-195]. Work, as a purposeful human activity, is directly enforced by the second law of thermodynamics as a reaction to the inevitable increase in entropy. Through labor, the decline in the depreciation of objects is halted and the existence of being is prolonged.

Physics, of which thermodynamics is a solid pillar, is a natural science focused on the study of matter and energy, in which it has achieved great cognitive and practical success. So are chemistry and biology, natural sciences that make extensive use of thermodynamics. The question arises, then, what is the place of economics among the sciences, and why does economic knowledge, in its service to man, stand so far apart from the aforementioned natural sciences? This is not a criticism, but a statement of the existing state of affairs in practice. Lack of sound scientific foundations, unclear concepts (capital, sources of profit, labor, frequent crises, etc.) indicate a science far from the category of science. This opinion does not apply to the theory of accounting, an economic discipline about which there are currently grounds to consider it a natural science [Dobija, Renkas, 2020].

The central thesis of this article is that the weakness of economics is due to its lack of natural thermodynamic foundations. These foundations include two fundamental principles (the first and second principles of thermodynamics), without consideration of which little can be properly defined and explained, especially the knotty economic categories such as capital, labor, value, and money. The main task of the paper, however, is to present economic concepts and to create a conceptual structure in correspondence with the natural and indispensable knowledge of physics, however, emphasizing the differences that separate economics from physics. The essential separator is the discovered economic constant, which quantifies in particular the influences of Nature on economic performance and is therefore indispensable in the theory of capital.

There are many physical principles that describe our reality and the laws of thermodynamics occupy a prominent place among them. Two fundamental laws; the first and second principles of thermodynamics are particularly important in the aspect of economic science and they form the basis for consideration. In fact, there are four principles of thermodynamics; in addition to the first and second, there are the zero and the third, but their relation to the economic sciences seems tenuous at this stage of their development. The third principle states that 
there are no processes that bring objects to a temperature of absolute zero, at which entropy no longer appears. The following formulation defines the first law of thermodynamics.

The change in internal energy of an object, is equal to the sum of the energy supplied by heat and the work done on the object. In contrast, in an isolated system, the principle of conservation of energy applies: The conservation of energy principle states that the sum of all types of energy in an isolated system is constant. It follows that energy cannot be created from nothing, nor can it disappear from the system. Transformations of energy within the system are possible, but the total energy is constant. The second principle of thermodynamics (SPT) has at least three equivalent formulations:

(Kelvin) It is not possible to have a process whose only result would be to do work equivalent to the heat received from a source; (Clausius) No such process is possible whose only result would be the transfer of heat from a cold body to a hot body; (Entropic) The entropy of an isolated system does not decrease.

It is significant that these three formulations are equivalent [Adamczyk, 2008], and each can be expressed in a more convenient term. Therefore, the explanatory power of SPT is enormous. For example, Sir Kelvin's natural formulation of the principle specifies that a heat engine cannot operate without a radiator, the latter not necessarily being a viable object built for that purpose. There have been working automobiles without a radiator, and its role has been fulfilled by the environment. The same is true of the organisms of living beings. On the other hand, in the equivalent version of entropy, SPT means that disorder is steadily increasing in the object.

\section{The duality principle bridges the gap between economics and thermodynamics}

The relationship between material objects and energy is explained in physics. And so potential energy relates to a material object located at a certain height from the surface of the earth, while kinetic energy relates to an object in motion. And the most important relationship, E $=\mathrm{mc}^{2}$, is wonderful from a theoretical point of view, but much less effective in practice. It can apply to uranium atoms, the splitting of which yields $1 \%$ of the theoretically available energy [Dewdney, 2004, p 37]. So it is far from a state where 100\% of the mass of any element is converted into pure energy without radioactive residues.

In economic sciences, mainly accounting theory, the principle of dualism applies, according to which economic resources are viewed dualistically as heterogeneous material assets and the abstract capital embodied in them. Therefore capital represents the potential of the ability to perform work of a given object (machine, installation, man), which is depreciated (dissipated) and when the limit of reduction of capital content is exceeded, the object becomes scrap or other remnants. Abstract capital is therefore embodied in matter, from which assets are formed.

The thermodynamic provenance of capital is clear; moreover, the duality principle leads to the relationship of capital to the first and second principles. The duality principle is a discursive expression of the basic identity of accounting $\left(\mathrm{A}_{0}=\mathrm{C}_{0}\right.$, where $\mathrm{A}$ and $\mathrm{C}$ stand for the value of assets and capital) and reveals clear connections with the principles of thermodynamics. From its consistent application arises the need to use the dual recording of economic operations, which in turn enforces that neither capital nor assets arise from nothing, a property of the first law of thermodynamics.

In practice, the principle of dualism leads to the use of identity with the division of capital into own and foreign, that is, property rights are taken into account. This developed formula is presented as:

$$
\mathrm{A}_{0}=\mathrm{C}_{0}=\mathrm{E}_{0}+\mathrm{D}_{0}
$$

Where E - represents the value of capital belonging to the founders of the economic unit and D - represents the value of foreign capital, borrowed and used in economic processes carried out by the economic unit. The equation in this form is used in practice to organize financial accounting systems and at the same time to teach accounting at the basic level.

A periodic measure of capital change is achieved by considering two moments of time, for example, the beginning and end of the year. Then from the two relationships: $A_{0}=E_{0}+D_{0}$ and $A_{1}=E_{1}+D_{1}$, the periodic increments of economic quantities can be calculated. Transforming the initial equations one arrives at the formulas:

Income $=\Delta \mathrm{E}=\mathrm{E}_{1}-\mathrm{E}_{0}=\left[\mathrm{A}_{1}-\mathrm{A}_{0}\right]-\left[\mathrm{D}_{1}-\mathrm{D}_{0}\right]=\Delta \mathrm{A}-\Delta \mathrm{D}$

That define the measurement of changes in equity (E), which is called profit when $\Delta \mathrm{E}>0$. This way of measuring this key economic category has been applied since at least the 15 th century and is a significant tool for practical economic action. It is for income that economic organizations are created, where founders and other investors pool the resources of owned assets to generate capital gains. And making a profit means, first and foremost, the sustainability of the organization, as well as opportunities for growth and appropriate shareholder benefits. Profit from economic activity is a critical indicator of an organization's existence, but it is not the case that it is the only, perfect and absolute determinant of the organization of social and economic life. Economics in the form of a social market economy requires much more intellectual effort.

From a thermodynamic point of view, we will note that in the presented system of measurement of capital changes is perceived respect for the first principle of thermodynamics. The record of economic operations is in form of the double-entry, according to formula (1). This means, among other things, that the dual accounting system does not allow capital to arise from nothing. The first principle of thermodynamics in this context is narrowed to the economic unit, so capital can disappear naturally or, for example, as a result of an asset fire. With the double entry of economic operations, capital does not arise from nothing, so that periodic changes in capital can be measured. The economic importance of this category forces to solve the following cognitive problems. What is the source of capital and income, what is the role of labor in creating profit?

According to the second principle, this abstract capital inherent in assets is subject to spontaneous and random dissipation, which manifests itself in aging, depreciation of physical objects (entropy increase). Income accounting needs to take this fact into account, as illustrated by an example. An organization purchases a production device for the amount of $£ 120,000$. It is expected to operate the device for 5 years, and after this period the residue is valued at $£ 10,000$. A natural application of the entropic version of SPT leads to the equation:

$120000 \times \mathrm{e}^{-\mathrm{d} \times 5}=10000$

Where $\mathrm{d}-$ is the residual value index. Hence, $\mathrm{d}=0.49698133 \sim 0.5$. Table 1 calculates the annual depreciation amounts for a device with an initial value of 120,000 and a useful life of 5 years. The last column contains the index to the current balance method. 
Table 1: Calculation of Theoretically Justified Depreciation Amounts

\begin{tabular}{lllll}
\hline Year & Value exp[-dxt] & End of year value (zł) & Depreciation amount (zt) & \multicolumn{2}{l}{ Fixed percentage of reduction of current bal- } \\
ance
\end{tabular}

Source: personal elaboration.

The principle of dualism also makes it possible to explain the essence of capital. Let us note that the complete disappearance of capital in an object leads to the loss of the essence of that entity; to the interruption of its existence as an intentionally created artifact. The existence of capital determines the persistence of the object and the fulfillment of its designated functions. Capital, then, can be defined as the potential capacity to act, to do work, which devices, objects and products possess from the beginning of their existence. Labor, on the other hand, is the transfer of capital to labor objects, so it proves to be complementary to capital. Labor represents the dynamic aspect of capital, which is inherently potential. The definition of capital is consistent with the perception of energy in the natural sciences. Therefore, thermodynamics is indispensable in formulating theoretical explanations of capital, human capital, profits, and fair wages.

\section{Labor versus sources of profit. revealing the economic constant}

From the definition and nature of capital comes the complementarity of the categories of labor and capital. While capital represents potential, labor appears as the dynamic transfer of capital to labor objects. Thus, there is no work without pre-existing capital (for example, human capital). In turn, labor transfers existing capital to labor objects, which constitutes their cost value. From this comes the important conclusion that labor has a specific, not direct function in the process of capital growth, i.e., profit creation. Labor is a transfer of capital, so it does not directly increase capital that must have already existed. When a shoemaker makes shoes, his human capital integrates with the capital contained in materials and tools and a shoe with a certain cost value is created. This plus the anticipated costs of uncertainty and risk creates a price and then a market value. So the question of the sources of profit is an important one that has occupied economists for decades, and unequivocal opinions have not yet emerged.

Modeling changes in capital leads to the question of sources of profit. Consider a useful object containing initial capital $\mathrm{C}_{0}$, for example, a production line or a cultivated field with sown grain. According to SPT, $\mathrm{C}_{0}$ is affected by a factor (negative compound percent) that reduces the value of capital $\mathrm{e}^{-\mathrm{st}}$ in time, where $\mathrm{s}$ is the rate of reduction and t represents the passage of calendar time. The object with time decreases utility (equipment needs repairs, weeds appear on the land), so planned repairs and needed actions are made), that is there is an inflow of capital through labor $\mathrm{e}^{\mathrm{mt}}$. As a result, after the calculation period there is an increase in the initial capital $\Delta \mathrm{C}$, that is, profit appeared. It should be noted that the processes of labor only transferred the already existing capital, so nothing has changed in the overall balance of capital. Therefore, the conclusion is that the growth of capital is caused by natural forces, which is captured by the eat factor, where "a" is an economic constant. This is clearly seen in the case of sown grain, where photosynthesis and nature were at work. In the operation of a production line, capital growth occurs due to the influence of human capital (increased experience, innovation, productivity). As a result, the capital change model can be summarized as follows:

$\mathrm{C}_{\mathrm{t}}=\mathrm{C}_{0} \times \mathrm{e}^{-\mathrm{st}} \times \mathrm{e}^{\mathrm{mt}} \times \mathrm{e}^{\mathrm{at}}=\mathrm{C}_{0} \times \mathrm{e}^{(\mathrm{a}-\mathrm{s}+\mathrm{m}) \mathrm{t}}, \mathrm{a}=\breve{\mathrm{E}}(\mathrm{s})=0,08[1 /$ year $]$

The size of the economic constant $\mathrm{a}=\breve{\mathrm{E}}(\mathrm{s})(\breve{\mathrm{E}}$ - the symbol of the average value) results from empirical studies. The determination of this constant consists of the study of the "risk premium" realized in stock trading and the study of ROA determining the rate of profit from the sum of capital invested in the economic unit. The basis of model (4) is the first and second principles of thermodynamics. Capital is not created from nothing as indicated by the need for $\mathrm{C}_{0}$ and the variable (s) determines the dissipation of capital.

From model (4) it is clear what quantities affect the formation of profit. A formal calculation leads to the formula:

Income $=\Delta \mathrm{C}=\mathrm{C}_{1}-\mathrm{C}_{0}=\mathrm{C}_{0}(\mathrm{a}-\mathrm{s}+\mathrm{m})=\mathrm{C}_{0}[\mathrm{a}-(\mathrm{s}-\mathrm{m})]$

It can be seen that labor " $\mathrm{m}$ " can reduce the destructive effects of SPT and, for a firm with good management and a properly functioning accounting and finance system, reduce them to zero. Then the result will be close to the economic constant, i.e. average ROA = a. The conclusion is that the economic constant determines the direct contribution to profit. Live and clotted labor in assets only offsets the destructive influence of SPT. On the other hand, it can be said that the SPT, by introducing destruction, at the same time forces an attitude of productive and effective work. It is therefore the causal cause of the development of science, technology and economics. The SPT dialectic unites opposites.

So how should an economic constant be interpreted? J. Barrow [2002], who produced a major work describing the role of Nature's constants, wrote in the conclusion (pp. 290-291) that: "...our discovery of the laws of Nature's operation and the rules for making change has led us to the discovery of the mysterious numbers that determine the structure of all that exists. The constants of Nature provide a bulwark protecting science from unbridled relativism..." The economic constant quantitatively defines Nature's influence on the outcomes of rational management. Viewing economics as a non-zero positive-sum game with Nature, one might think that the constant indicates that this added value is $8 \%$ of the initial capital. That is, the economy can achieve a level of capital multiplication at an average rate of 0.08 [1/year]. This conclusion leads to a representation of the economy as in Figure 1. 


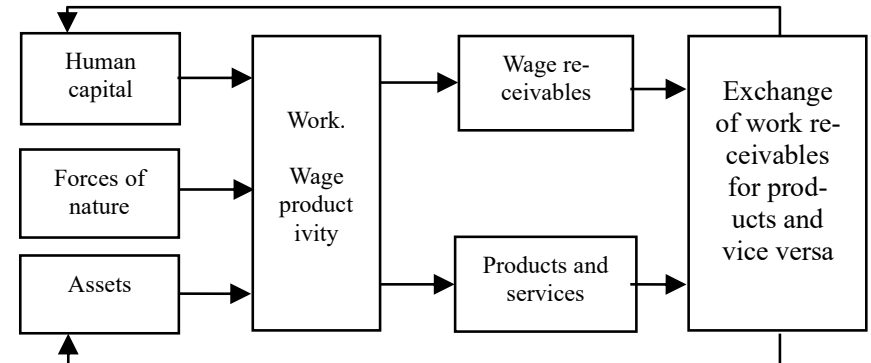

Diagram 1: The Process of Production, Exchange and Distribution in A Commodity-Money Economy. Source: (Dobija \& Kurek, 2013, P. 300).

Diagram 1 shows the natural flows of capital in the processes of work, whose sources are: human capital (live labor) and assets (clotted labor) and the forces of nature of which photosynthesis is extremely important, which allows the conversion of the sun's energy into biomass, which is the basis for the formation of human capital. Labor generates two elements: products and dues (work receivables) for living labor, i.e. money which is an absolute right to receive the equivalent. Money exchanges in a free market for products and this is the essence of a commodity-money economy. Money and products feed the value of assets and support the development of human capital. Recognizing the validity of the presented interpretation of the nature and sources of profit, one should see the correct direction of thinking by F. Knight [1921], who already in the title of his work distinguished between risk and uncertainty. He assumed that measurable uncertainty is risk, while unmeasurable uncertainty is uncertainty sensu stricto, or, as we might say, is the effect of SPT. In model (4), uncertainty, i.e., the random and spontaneous accumulation of entropy, is determined by the variable (s) representing the effects of SPT. This uncertainty is constrained by efficient and productive work. Risk, on the other hand, is associated with the projects undertaken. It can be greater or lesser and always determines the potential for loss. Risk represents a threat to profit.

\section{Estimating the value of an economic constant}

Of particular note in Figure 1 is the role of natural forces manifested in the presence of an economic constant of potential growth. As it turns out, there are many areas in which this constant manifests itself, so its value can be estimated. The constant "a" can be identified and estimated from periodic earnings and return data on stocks. This type of research has previously been conducted to assess the "risk premium". This quantity, defined as the difference between the real rate of return and the return on U.S. Treasury receipts, is a component of the CAPM model [Ibbotson \& Goetzmann, 2006], which has lost much of its appeal in the current era. Our interpretation of the data is somewhat different and comes from a proper view of the sources of profit. Since labor only offsets the destructive effect of the passage of time (second law of thermodynamic) by contributing to capital preservation, the fundamental source of capital gains must be natural forces. In this state of affairs, the size of the constant can be estimated by examining the real rate of return achieved on the efficient stock market (Table 2) or by examining ROA. Data on rates of return on equities are provided in Table 2.

Table 2: Summary Statistics for Returns on U.S. Stocks, Bonds and Treasury Bills (1926-2004)

\begin{tabular}{|c|c|c|c|c|c|}
\hline Specification & Stocks & Long-Term Government Bonds & Treasury Bills & Inflation & Real rate of return \\
\hline Arithmetic average & $12.39 \%$ & $5.82 \%$ & $3.76 \%$ & $3.12 \%$ & $9.27 \%$ \\
\hline Geometric average & $10.43 \%$ & $5.44 \%$ & $3.72 \%$ & $3.04 \%$ & $7.39 \%$ \\
\hline Standard deviation & $20.31 \%$ & $9.30 \%$ & $3.14 \%$ & $4.32 \%$ & $8.33 \%$ \\
\hline
\end{tabular}

Source: own elaboration based on [Ibbotson, Goetzmann, 2006, p. 35].

To calculate the rate of return based on the data in Table 4, the percentage of inflation was subtracted from the return on stocks, which gave the value: $12.39-3.12=9.27 \%$ calculated according to the arithmetic average. Whereas, according to the geometric average it is $10.43-3.04=7.39 \%$. This range (7.39-9.27) includes the average long-term rate of return achieved on the American capital market. To arrive to score was calculated the arithmetic mean of these two numbers and was obtained a value of $8.285 \%$. For stock market and reporting corporate profits, the data indicates the value at the end of the accounting year. Therefore, if capital grows at the rate of $8 \%$ (ex ante), then at the end of the year (ex post) it reaches level $\mathrm{e}^{0.08}-1$, which is about $8.33 \%$. Thus, the estimation specifies a $=0.08$ [1/year].

The size of the economic constant at $8 \%$ [1/year], as shown by B. Kurek [2012], is also confirmed by the rates of return on capital directly invested in business units. The author conducted a study of ROA on a sample of financial statements of companies belonging to the Standard \& Poor's 1500 index for a period of 20 consecutive years. The total number of observations obtained was 22,952. The study was conducted at a confidence level of 0.999 , obtaining a confidence interval of 8.25-8.89\%. B. Kurek's statistical results showed an average ex post return on capital of $8.33 \%$ per year, which is equivalent to $8 \%$ ex ante.

As we can see, there are many areas in which economic constant manifests itself and its value can be estimated. Established laws throughout history are no exception. According to A. Pikulska-Robaszkiewicz [1999, pp. 41-42], in the Republic of Rome the interest rate on granting a loan was legally limited and defined as $1 / 12$ of capital, i.e. $8.33 \%$ per annum. Maintaining this limitation, Emperor Justinian freed contracts from unjustified ruining percentage. This decision was a reasonable compromise between humanitarianism and the necessary needs of trading, which revealed the effect of the natural rate of capital multiplication. Later, the introduction of a similar limit for interest in a maritime loan enabled the development of maritime trade. All this showed that economic development occurred after allowing the operation of the natural rate of capital multiplication, that is, the constant $\mathrm{a}=0.08$ [1/year]. It is also evident that under early capitalism the class of annuitants receiving interest on bank deposits at $8 \%$ could enjoy excessive, undeserved benefits.

\section{The thermodynamic foundations of theories of employee human capital measurement}

The basic scientific concepts for thermodynamics viewed in economic terms are: energy, work, heat, entropy. As P. Atkins [2005, p. 158] writes, abstract heat engines operate in the human organism (also in animals), the operation of which is connected, among others, with the ATP molecule (adenosine triphosphate, which is a universal energy carrier), the bonds of which provide the organism with energy, losing in the process a part of its transferred to the environment through heat, which is commonly felt. In fact, ATP is broken down and the ADP molecule (adhesinodiphosphate) is formed, and with this dissipation of matter the energy needed by the cells is released, some of which 
does not do work. For the preservation of life and existence, the reverse process driven by appropriate metabolic reactions also occurs. Through food and metabolic processes, ADP is converted back into ATP with a phosphate group as an energy reservoir.

P. Atkins [2005, p. 158] shows the cascade of "steam engines" whose work and dissipation of energy make up the process of existence of living organisms.

To create food, in turn, even more powerful heat engines are needed to dissipate energy and matter even more efficiently. The most important of these is the sun, because the energy the sun dissipates into the environment drives the reactions of photosynthesis, the formation of hydrocarbons from water and carbon dioxide. Ultimately, then, the driving force behind our actions and aspirations is the energy released when atomic nuclei fuse on the Sun.

The pervasive presence of SPT is revealed here, and above all its not only destructive but also beneficial effects. While the heat passing into the atmosphere with car exhaust has no value, the heat emitted as a side effect by human or animal bodies is, in most situations, a positive value for building family bonds and raising offspring. Keeping in mind that according to SPT (p 154): "Where something is built, there always something - at least in equal measure and in connection with that construction - falls into ruin" it is worth not forgetting and also the great positive influence of SPT on the reality in which we live.

Erwin Schrödinger [1967], the founder of quantum mechanics (Schrödinger's wave function) addressed the question of DZT in an entropic interpretation in his essay wondering why humans can keep their living organisms alive for so long. He asks, what causes a living organism to avoid dying? And he answers.

Any process or event, never mind the name, anything that happens in nature leads to an increase in entropy in that space in which it takes place. Thus every living organism produces positive entropy and its entropy is constantly increasing. It approaches the state of maximum entropy, i.e., death, and can only stay alive by drawing negative entropy from its environment, which is something positive for it. It feeds it.

The author justifies the use of the term negative entropy by using L. Boltzman's formula in the form $S_{n}=k \times \ln D^{-1}$, where: $k$ - Boltzmann's constant, $\mathrm{D}^{-1}$ is the inverse of the disorder measure $\mathrm{D}$ (colloquial term), $\mathrm{S}_{\mathrm{n}}$ - negative entropy. It is very valuable that this outstanding European intellectualist paid attention to man's use of "order" existing in nature or created consciously by man. Such things are undoubtedly medicines for diseases, vitamins and various dietary supplements. The latter are significantly used by the elderly, whose bodies have to some extent lost the ability to sufficiently absorb these compounds from food.

It should be noted, however, that this satiation with order, of which E. Schrödinger writes, has been reasonably applied since the beginning of civilization, and consisted in taking care of the balance of the elements. The problem is, however, that modern physics distinguishes between potential and kinetic energy, and does not recognize the energies called elements, on the basis of which the knowledge of balanced nutrition was created, as well as the predispositions of people under the influence of certain elements or the lack thereof. And this is common knowledge for billions of people in the world, especially the Chinese population.

M. Mazur (p. 224-239) combining cybernetic and thermodynamic approaches introduces categories of physiological and sociological power, which participate in the control of the autonomous system, and their changes determine its behavior. The processing of physiological power is possible, writes the author (p. 226-227), as long as the structure of the autonomous system is maintained, so it depends on the durability of the material of this system. In turn, the durability of the material depends on the persistence in it of a certain concentration of energy, the bringing of which has contributed to the formation of the autonomic system. Over time, the plastic ages and the physiological power decreases, which reduces the ability of the autonomous system to control itself and maintain equilibrium, so to counteract this, the organism increases the amount of plastic by expanding. If $\mathrm{C}$ is the expansion factor and $\mathrm{A}$ is the aging factor, then the dynamism factor is determined by the formula $\mathrm{n}=$ C/A. Taking into account the necessary idle power in the system, we arrive at a formula determining the course of physiological power and disposable power, which depends mainly on the quality of the material and the aging coefficient.

Analyzing the physiological and disposable power generated by the human body, one can obtain important indications for the construction of remuneration systems, as well as for the formulation of human developmental goals. The point is that physiological power is the sum of idle, working and free power. With a minimum wage, only the idle and working power are covered, which is a slave-like situation. It is only when the free power is used appropriately that it is possible to improve the situation and to direct it towards meaningful development and satisfaction with the existing life situation.

Using the estimates of disposable power made by M. Mazur (p. 232-237) it is possible to attempt to estimate the average annual rate of depletion of human disposable power. Man reaches his maximum power at the age of about 27 years. In turn, the Book of Genesis indicates the end of man's life at about 120 years. Taking the maximum of disposable power as 1.0 one can ask about the average rate of loss of this power during the period $120-27=93$ years. For calculations, one needs to take the power value at age 120 as being close to zero, for example, 0.5 per mille $(0,0005)$ of the initial value. Solving the equation $\mathrm{e}^{-93 \mathrm{~s}}=0.0005$ gives the result $\mathrm{s}=0.0817$, i.e. the average annual loss of available power is about $8 \%$.

The human capital measurement model is derived from the interpretation of model (4). Taking the human capital label $(\mathrm{H})$ identifies the subsequent impacts on the initial capital $\mathrm{H}_{0}$. Thus, SPT introduces the factor $\mathrm{e}^{\text {-st }}$ where the random variable "s" represents the decay of initial potential and inputs and current labor (factor $\mathrm{e}^{\mathrm{mt}}$ ) are needed to offset these impacts. These inputs are the labor of parents and society and the matter necessary for the growth of the organism. A human being needs warmth, food, clothing and shelter. In addition to these, forces of nature quantified by the constant "a", in particular order, or negative entropy, which E. Schrödinger [1967] wrote about, have a positive influence on human development.

Taking into account the listed variables, the heuristic formula (6) representing the changes in human capital over time is obtained.

$\mathrm{H}(\mathrm{t}, \mathrm{a})=\mathrm{H}_{0} \times \mathrm{e}^{-\mathrm{st}} \times \mathrm{e}^{\mathrm{mt}} \times \mathrm{e}^{\mathrm{at}} \mathrm{a}=0.08[1 /$ year $]$

The interpretation of formula (6) leads to the basic model (7) of personal human capital measurement.

$H(a, t, T)=[K(a, t)+E(a, t)] \times[1+L(T, u)]$

Where H(a,t,T) - worker's personal capital after $t+T$ years of life, $t$ - number of years to the first job, $K(a, t)$ - capitalized cost of living expenditures. $\mathrm{E}(\mathrm{a}, \mathrm{t})$ - capitalized outlays of professional education, $\mathrm{L}(\mathrm{T}, \mathrm{u})$ - experience growth factor over $\mathrm{T}$ years of employment with the learning ability "u".

Model (7) is formed by considering the following information. The initial capital of the offspring (infant) is not included in the economic calculation. As a natural element, it takes a neutral value, so $\mathrm{H}_{0}=1$. The labor and inputs provided by parents and society offset the dispersion of capital (the effect of the $\mathrm{e}^{-\mathrm{st}}$ factor) and, together with the $\mathrm{e}^{\text {at }}$ factor, form the components $\mathrm{K}(\mathrm{a}, \mathrm{t})$ and $\mathrm{E}(\mathrm{a}, \mathrm{t})$. The factor $1+$ $\mathrm{L}(\mathrm{T}, \mathrm{u})$ determines the increase of capital from experience dependent on the number of years of work $\mathrm{T}$ and the learning ability " $\mathrm{u}$ ". 
Another application of SPT leads to a model of fair compensation for labor. Personal capital is subject to natural, spontaneous dissipation. To sustain the value of the worker's capital one needs to balance the dissipation with an adequate value of the wage. The rate of dissipation is determined by a random variable "s" with mean value "a". Thus, the wage formula $\mathrm{W}$ is defined by equation ( 8 ) as follows:

$\mathrm{W}(\mathrm{a})=\mathrm{a} \times \mathrm{H}(\mathrm{a}, \mathrm{t}, \mathrm{T})$

Models (7) and (8) form the core of the theory of measurement of personal human capital and adequate compensation for the work of this capital. They enable empirical studies of the economic constant "a", which invariably confirm the size of a $=0.08[1 /$ year] . Wages determined by formula (8) have the property of preserving the personal capital of employees.

\section{Empirical verification of human capital models}

For the human capital of a person without professional education and work experience (for example, for a 17-year-old), model (7) is restricted to: $\mathrm{H}(\mathrm{a}, \mathrm{t})=\mathrm{K}(\mathrm{a}, \mathrm{t})$, which means that we consider only capitalized living costs. As indicated in [Renkas, 2017a, 2017b] these are determined using continuous capitalization: $\mathrm{K}(\mathrm{a}, \mathrm{t})=\mathrm{k}\left(\mathrm{e}^{\mathrm{at}}-1\right) / \mathrm{a}$, where $\mathrm{k}$ is the annual cost of living. Transforming formula (8) we arrive at a formula that can be used to estimate the constant "a" taking into account the real minimum wage in the calculation:

$W_{R}=\mathrm{a} \times \mathrm{K}(\mathrm{a}, \mathrm{t})=\mathrm{a} \times k \times \frac{\mathrm{e}^{\mathrm{at}-}-1}{\mathrm{a}}$

Where: wR - real minimum wage, a - economic constant, $\mathrm{t}$ - number of years, $\mathrm{k}$ - annual cost of living.

Using formula (9), the value of the economic constant "a" is estimated using the example of the real minimum wage in the USA. The USA economy was chosen for the study because of the widespread desire to migrate to that country, which indicates the fairness of the minimum wages there. The above formula (9) is transformed to the form:

$\mathrm{a}=\frac{1}{t} \ln \left[\frac{W_{\text {LSA }}}{k}+1\right]$

Where: WusA - the actual minimum wage in the United States.

Using the formula (10) the value of "a" is calculated for a few selected states. It is common knowledge that in Washington D.C. as of July 1,2020 , the statutory minimum wage is set at USD15 per hour. Adding $7.65 \%$ of the employer's costs to this amount yields the total cost of hiring an employee. On a monthly basis, this amount is: 176 hours $\times$ USD16.15/hour $=$ USD2,842.4. The monthly cost of living ( $\mathrm{k}$ ) in Washington D.C. is estimated to be USD848 ${ }^{1}$. Thus, assuming a person of age 17 for the calculation, one obtains: $\mathrm{a}=\frac{1}{17} \ln \left[\frac{2842,4}{848}+1\right]=0,0865$. In other selected states, the estimation leads to similar results (Table 3).

Table 3: Estimation of Size "A" Based on Real Wages in Selected U.S. States (2020)

\begin{tabular}{|c|c|c|c|c|c|}
\hline City and State & $\begin{array}{l}\text { Washington } \\
\text { D.C. }\end{array}$ & Boise, Idaho & $\begin{array}{l}\text { Denver, Colo- } \\
\text { rado }\end{array}$ & Omaha, Nebraska & $\begin{array}{l}\text { Louisville, } \\
\text { Kentucky }\end{array}$ \\
\hline The size of the constant "a" & 0,0865 & 0,0751 & 0,0834 & 0,0809 & 0,0754 \\
\hline Monthly cost of living for a family of four, USD & 3392,00 & 2124,00 & 3115,00 & 2309,00 & 2108,00 \\
\hline Monthly cost of living per person (k), USD & 848,00 & 531,00 & 779,00 & 577,00 & 527,00 \\
\hline $\begin{array}{l}\text { Number of years of maintenance cost capitalization } \\
\text { (t) }\end{array}$ & 17 & 17 & 17 & 17 & 17 \\
\hline $\begin{array}{l}\text { Wages, determined from a human capital model using } \\
\text { the constant } \mathrm{a}=0.08 ; \text { USD/hour }\end{array}$ & 13,95 & 8,74 & 12,82 & 9,49 & 8,67 \\
\hline Statutory minimum wage*, USD/hour & 16,15 & 7,80 & 13,83 & 9,69 & 7,80 \\
\hline $\begin{array}{l}\text { Percentage of compliance between statutory and theo- } \\
\text { retical wage }\end{array}$ & $115,76 \%$ & $89,28 \%$ & $107,91 \%$ & $102,07 \%$ & $89,96 \%$ \\
\hline City and State & $\begin{array}{l}\text { Orlando, } \\
\text { Florida }\end{array}$ & $\begin{array}{l}\text { Boston, Massa- } \\
\text { chusetts }\end{array}$ & $\begin{array}{l}\text { Oakland, Cali- } \\
\text { fornia }\end{array}$ & $\begin{array}{l}\text { Providence, } \\
\text { Rhode Island }\end{array}$ & $\begin{array}{l}\text { Portland, Ore- } \\
\text { gon }\end{array}$ \\
\hline The size of the constant "a" & 0,0744 & 0,0831 & 0,0805 & 0,0850 & 0,0866 \\
\hline Monthly cost of living for a family of four, USD & 2552,00 & 3113,00 & 3359,00 & 2453,00 & 2989,00 \\
\hline Monthly cost of living per person (k), USD & 638,00 & 778,00 & 840,00 & 613,00 & 747,00 \\
\hline $\begin{array}{l}\text { Number of years of maintenance cost capitalization } \\
\text { (t) }\end{array}$ & 17 & 17 & 17 & 17 & 17 \\
\hline $\begin{array}{l}\text { Wages, determined from a human capital model using } \\
\text { the constant } a=0.08 ; \mathrm{USD} / \text { hour }\end{array}$ & 10,50 & 12,80 & 13,82 & 10,09 & 12,29 \\
\hline Statutory minimum wage*, USD/hour & 9,21 & 13,73 & 13,99 & 11,30 & 14,26 \\
\hline $\begin{array}{l}\text { Percentage of compliance between statutory and theo- } \\
\text { retical wage }\end{array}$ & $87,74 \%$ & $107,26 \%$ & $101,23 \%$ & $112,04 \%$ & $116,03 \%$ \\
\hline $\begin{array}{l}\text { Average value of the constant "a" from the } 10 \text { states } \\
\text { tested }\end{array}$ & 0,0811 & & & & \\
\hline $\begin{array}{l}\text { The mean value of the percentage of compliance from } \\
\text { the } 10 \text { states tested }\end{array}$ & $102,93 \%$ & & & & \\
\hline
\end{tabular}

* Statutory hourly wages were increased by the percentage of contributions (Social Security Tax and Medicare Tax) paid by the employer (7.65\%) ${ }^{2}$. Cost of living data were taken from [Cost of living in USA, 2020]. Source: own elaboration.

Also, calculations carried out for dozens of the largest cities of the USA show the value of the constant "a" at a level close to $8 \%$ [Dobija, Renkas, 2021, p. 5]. The results of calculations confirm that the minimum wage in the USA is determined by the constant "a" and its size is at a level close to 0.08 [1/year]. This constant determines the fair wage, which offsets the natural spontaneous loss of human capital guaranteeing its preservation. 
What is the essence of a fair wage? A fair wage means that the earnings of two working parents make it possible to bring at least two offspring up to the level of human capital achieved by the parents. It follows from this definition that human capital will be preserved, that is, the solution to the basic demographic problem is guaranteed. The calculations presented in Table 4 confirm that the theoretically determined minimum wage (formula 8) meets this condition. The calculations were made on average cost of living values using a constant "a". The calculation shows that after payment of the required contributions (pension and health funds), the amounts remaining to cover the cost of living are greater than the current amount of USD577.

Table 4: Income Settlement for A Family of Four

\begin{tabular}{ll}
\hline Country & USA (USD) \\
\hline Family (2 adults + 2 children) & 4 people \\
Income (sum of minimum wage of 2 adults) & 3410,35 \\
Pension contributions (20\%) & 682,07 \\
Health insurance (10\%) & 341,04 \\
Total amount of income remaining in the family & 2387,24 \\
Amount per person & 596,81 \\
Average cost of living & 577,00 \\
\hline
\end{tabular}

Source: own elaboration.

It is assumed that two parents receive earnings at the average minimum wage. It is also assumed that they pay a contribution of $20 \%$ for pension insurance and $10 \%$ for health insurance, which is the basis for creating funds for the health care of family members and the accumulation of pension funds. The remaining income covers the cost of living. The average cost of living in the United States is estimated to be USD577.00 3 . Parents' earnings are assumed to be the average minimum wage per hour (from all states) multiplied times 176 hours, viz: $2 \times$ USD9.00 per hour $\times 176$ hours $=$ USD3,168.00. After adding the $6.2 \%$ Social Security Tax and $1.45 \%$ Medicare Tax paid by the employer, the total family income is USD3,410.35. Assuming a $20 \%$ contribution to retirement and $10 \%$ to health insurance, the remaining income for a family of four is USD2,387.24. Per person will be: USD2,387.24 / 4 = USD596.81, which is more than the average cost of living of USD577. This means that the standard of living is maintained.

Note also that the wage assumed in the calculation represents the absolute minimum income. However, in reality, earnings increase over time due to the increase in capital from experience, so the amount left over for living expenses will be greater. From the above calculations, it can be seen that the minimum wage in the USA guarantees the preservation of human capital. Thus, the wages studied can be considered fair. In addition, let us note that with the cost of living preserved, the family accumulates funds for health care and the parents capitalize their retirement funds.

Wage expectations also can be a source of data for estimating the economic constant "a". The size of the economic constant was examined using data from the Ukrainian economy. Surveys from five different regions provided the data. The questionnaires were prepared in the Labour Offices, obtaining data from job seekers. 3920 people were surveyed asking for data necessary to calculate the value of human capital (age, education, work experience) and the expected wage in case of employment. The choice of survey location is dictated by the fact that the job seeker does not manifest excessive expectations, but counts the cost of living for the whole family.

Using formula (7), net fair basic wages were determined for the respondents starting from the level of their accumulated human capital $(\mathrm{W}(\mathrm{a}, \mathrm{t}, \mathrm{T})=\mathrm{a} \times \mathrm{H}(\mathrm{a}, \mathrm{t}, \mathrm{T}) / 12 / 1,415$, where: $\mathrm{W}(\mathrm{a}, \mathrm{t}, \mathrm{T})$ - fair net basic wage, a - economic constant (8\% [1/year]), H(a,t,T) - the value of human capital, 1.415 - the amount of reduction by the amount of social benefits, paid by the employee and the employer, and income tax; total 41.5\%). Comparing the theoretical wages determined on the basis of formula (7) with the expected wages indicated by the respondents, the percentage of compliance of these wages was estimated. Basic statistics describing the obtained compliance percentages for 3,920 respondents are summarized in Table 5.

Table 5: Basic Statistics of the Percentage of Agreement between Expected and Set Wages Based on Human Capital Theory

\begin{tabular}{ll}
\hline Statistical quantities & Percentage of agreement between expected wages and wages determined from the theoretical model \\
\hline Average value & $100,30 \%$ \\
Median & $100,43 \%$ \\
Standard deviation & $0,048 \%$ \\
Number of surveys & 3920 \\
\hline
\end{tabular}

Source: own elaboration.

The statistics presented in Table 8 indicate a very high level of agreement between expected wages and those determined from the theoretical model, which includes in the calculations the assumed size of "a" (8\% [1/year]). Thus, the research hypothesis is that a constant quantity is identified in the wage expectations of job seekers that determines the average annual rate of natural dissipation of capital values. Transforming model (7) to the form $\mathrm{a}=\mathrm{W}_{\mathrm{O}} / \mathrm{H}(\mathrm{a}, \mathrm{t}, \mathrm{T})$, where $\mathrm{W}_{\mathrm{O}}$ - the expected wage of the respondents, $\mathrm{H}(\mathrm{a}, \mathrm{t}, \mathrm{T})$ - the value of their human capital, the estimator formula was obtained. The obtained statistics of "a" value calculation for 3920 respondents are summarized in Table 6.

Table 6: Descriptive Statistics of the Set of Obtained Quantities "A"

\begin{tabular}{ll}
\hline Statistical quantities & The value of "a" \\
\hline Average value & 0,079977 \\
Standard deviation & 0,005237 \\
Q1 & 0,078013 \\
Median & 0,079658 \\
Q3 & 0,081416 \\
Kurtosis & 208,49 \\
Sample size (n) & 3920 \\
\hline
\end{tabular}

Source: own elaboration.

As can be seen from Table 6 among the 3,920 respondents, the mean value of "a" in light of wage expectations, with a very small standard deviation (0.005237), is close to the magnitude of 0.08 which confirms the hypothesized value. Additionally, the probability distribution

\footnotetext{
${ }^{3}$ https://www.expatistan.com/cost-of-living/country/united-states (accessed October 10, 2020).
} 
is leptokurtic (highly slender). Thus, examining expected wages as a percentage of the human capital value of job seekers, confirmed the presence of a constant magnitude "a" at a level significantly close to $8 \%$.

Importantly, similar results were obtained by I. Cieślak [2008], B. Oliwkiewicz [2020] and B. Kurek \& I. Górowski, [2020] investigating wage expectations of economics graduates in Poland. Also, W. Kozioł [2011] statistically confirmed the existence of the economic constant at the level of $8 \%$ based on the analysis of real wages of a large number of employees of the Polish company ABM Solid SA. Thus, it is necessary to emphasize the important fact that the constant "a" in the size of $8 \%$ [1/year], as shown by the empirical studies presented in this article, is identified in the economies of different countries, so it is revealed regardless of the studied country.

\section{The thermodynamic core of coherent economic theory}

Knowledge of thermodynamics makes it possible to define precisely the basic economic categories, which has been a constant problem waiting to be solved. These include, in particular, capital, value, and sources of profit. Let us consider the question of capital, labor and money. It is known that Ch. Bliss, A. J. Cohen, and G. C. Harcourt [2005] collected 71 scientific texts, the authors of which presented their own views on the theory of capital. The differences in views were so great that they empowered the authors to form the opinion that capital theory is an infamous subject precisely because of the notoriously recurring controversies surrounding it. These controversies, as B. Kurek [2011, p 20-21] wrote, were the result of constant tensions between two concepts of capital: physical and value. Scholars had something to argue about. What is and what is the source of capital growth? what is its relationship to labor? why is there a positive interest rate? is capital a tangible asset or a fund? what is human capital? how does money relate to it? And what role does the passage of time play? These sample questions have not found consensual, unambiguous answers in scholars' discussions. It is now clear that for consensual explanations it was necessary to refer to the fundamental laws formulated in the natural sciences and properly interpreted for the economics. There was also a need to understand the abstract nature of capital on the basis of the principle of dualism and to discover the existence of a constant that determines the influence of natural forces on capital growth. This state of affairs concerning capital was summarized by Ch. Bliss [1975, p. vii], who stated, "that when economists reach consensus on capital, they will soon reach consensus on all other issues." He expressed doubt, however, whether this state would be reached in the foreseeable future. Even today one encounters expressions, for example T. Piketty [2015, p 63], who writes that:

Within this book, capital is defined as the totality of "non-human" assets that can be owned and exchanged on the market. Specifically, capital includes all real estate capital (buildings, houses) used for housing and financial and organizational capital (buildings, equipment, machinery, patents, etc.) used by businesses and administrations.

The familiar "capital vs. labor" or "machines vs. workers" oppositions in economics have also blocked the use of the scientific understanding of labor as the transfer of capital to labor objects, whether through live or clotted labor (various assets). Capital and labor are two complementary concepts. Capital represents the potential to do work, while labor is the dynamic transfer of capital. Labor concentrates capital into a product, which shapes its cost value and is the basis for the creation of utility and exchange value. Labor creates work receivables for labor, or money, as shown in Figure 1. Thus, money is the unconditional right to receive an equivalent in free exchange operations, which is to be guaranteed by the structures and standards of the rule of law and economics supported by sound knowledge. On this basis, a natural understanding of the commodity-money economy emerges, in which goods and services are exchanged for money and vice versa. As we see, the understanding of capital leads to a logical explanation of the essence of the main economic categories.

The scientific understanding of work allows us to use the achievements of physics regarding its measurement. We have two equivalent formulas for measuring work L. $\mathrm{L}=\mathrm{F} \times \mathrm{s} \times \cos \alpha=\mathrm{F} \times(\mathrm{v} \times \mathrm{t}) \times \cos \alpha=\mathrm{P} \times \mathrm{t} \times \cos \alpha$, where $\mathrm{F}$ - the force that causes the displacement, $\mathrm{s}$ the distance of the displacement, $\alpha$ - the angle between the direction of the displacement and the direction of the force $F, v-$ the speed of the displacement, $\mathrm{t}$ - the duration of work, $\mathrm{P}$ - the power attributed to the employee or object with the ability to perform work. If, for example, the salary of the managing director is 15000 PLN per month and the analyzed employee is paid 3000 PLN, then the power factor is $3000 / 15000=1 / 5$. Therefore, the work of the employee done for 200 hours in a month is $\mathrm{L}=1 / 5 \times 200=40$ work units. It is easy to see that a unit of money is also a unit of labor.

The factor $\cos \alpha$ has a natural economic interpretation (Kurek, 2004) and represents the compliance of work with socio-economic standards. Therefore, with full compliance, which is the natural state, $\cos \alpha=1$. However, we know cases where this factor should be taken into account. It is known that the calculation of GDP takes into account on the plus side the repair and renovation work done. However, if hooligans destroy a bus shelter at a bus stop, they also work, but with $\cos \left(180^{\circ}\right)=-1$, because their actions are anti-social and destructive. Taking this work into account as well, GDP will not show an increase from making repairs.

The understanding of capital and labor allows us to resolve the dispute over the production function. The authors [Cohen, Hartcourt, 2003, p. 199] cite the criticism formulated by J. Robinson [1953-1954, p. 81], regarding the production function in the form $P=f(L, K)$, where $\mathrm{L}$ - is labor measured in man-hours, and $\mathrm{K}$ - is capital perceived as machinery, equipment and money i.e. assets. Taking a constructive approach to this argument, it should be stated that manufacturing processes require a quantitative description of the connecting of abstract capital transferred by labor with assets. What is needed is a function that describes the linking of current labor with assets taking into account also the forces of nature.

The function of economic activity (FAE), presented in many previous studies [Dobija, 2011], [Dobija, Kurek, 2013] is described by formulas:

$\mathrm{P}=\mathrm{K}(1+\mathrm{r})=(\mathrm{W}+\mathrm{B})(1+\mathrm{r})=\ldots=\mathrm{W}(1+\mathrm{r})([1+\mathrm{A} / \mathrm{H} \times \mathrm{z} / \mathrm{u})=\mathrm{W} \times \mathrm{Q}(11)$

Where: $\mathrm{P}$ - value of annual output at selling price, $\mathrm{K}$ - total costs for the year, $\mathrm{W}$ - total wage costs, $\mathrm{B}$ - non-wage costs, $\mathrm{r}$ - profitability of costs ratio, A - average value of assets, $\mathrm{H}$ - total human capital employed (HCE), $\mathrm{z}$ - asset turnover rate relative to non-wage costs, $\mathrm{u}$ percent paid for labor relative to HCE, Q - labor productivity rate.

On the basis of function (9) a model of production is created using relation $1+\mathrm{c} \approx \mathrm{c}^{\mathrm{a}}$ and replacing variables (r, $\left.\mathrm{z}, \mathrm{u}\right)$ with one quantity called management variable $M$. This variable synthesizes impacts defined as: profitability of costs, assets turnover in relation to non-wage costs and percentage of paid work in relation to human capital value. These are variables subject to current managerial decisions as opposed to long-term variables like: A and $\mathrm{H}$. Thus, we obtain the model:

$P=W \times \exp \left[\frac{A M}{H}\right]$ 
Using the relationship $\mathrm{L}=\mathrm{a} \times \mathrm{H}$, where $\mathrm{L}$ is the value of fixed wages and " $\mathrm{a}$ " is the economic constant, the variable $\mathrm{H}$ is eliminated by the more readily available numerical variable $\mathrm{L}$.

$$
P=W \times \exp \left[\frac{A M a}{L_{L}}\right]
$$

Model (13) finds various applications. For example, it is possible to determine W - wages in a given market organization as a function of planned economic performance [Dobija, Jedrzejczyk, 2013]. If the planned production and sales are made with an undiminished management variable, then the amount $\mathrm{W}$ - L determines the size of the planned bonus fund.

The fixed salary set as 8 percent of the value of the employee's human capital plus the earned bonus creates decent financial conditions for the development of human capital in families of the type $2+2$ or $2+3$, when both parents work professionally. As research shows (Koziol, 2014, pp. 156-193), in enterprises, sustained in the market, the level of bonus pay usually exceeds $20 \%$. Thus, the total salary of an employee is $0.08 \mathrm{H}+0.2[0.08 \mathrm{H}]=0.096 \mathrm{H} \approx 0.1 \mathrm{H}$. A salary level of $10 \%$ guarantees not only the absence of depreciation but also the development of the personal capital of employees and offspring.

Understanding that in money - goods economy (MGE) there is no such thing as circulation of money, but money (dues for labor) naturally exchanges for goods and services, one sees the need to describe this process by an appropriate equation of exchange. From this equation, knowledge of the possible need and permissible size of credit should be derived. In addition, the role of taxes in economics should be clarified, since it is known that labor creates money, that is, labor finances itself. This equation has already been developed, presented and discussed [Dobija, 2011, 2013, 2015, 2020], [Dobija, Kurek, 2013].

The essence of MGE is that the work of the employed sets in motion the flow of two streams; products and money [costs of labor], as shown in Figure 2. These streams confront each other continuously, which shapes the resulting prices and profits. The market mechanism equalizes the value of the final product stream [GDP] and the money stream [M], ultimately shaping their purchasing power. Diagram 2 illustrates the fact that employees working, both in the industrial sphere and in the budgetary sphere, create labor costs that make up the value of products and at the same time receive an identical, nominal value in the form of a record of payments for work. On the product side there is the function of economic activity [FAE], which composes labor costs with assets, and in the money stream there is the function of credit money creation [CMC].

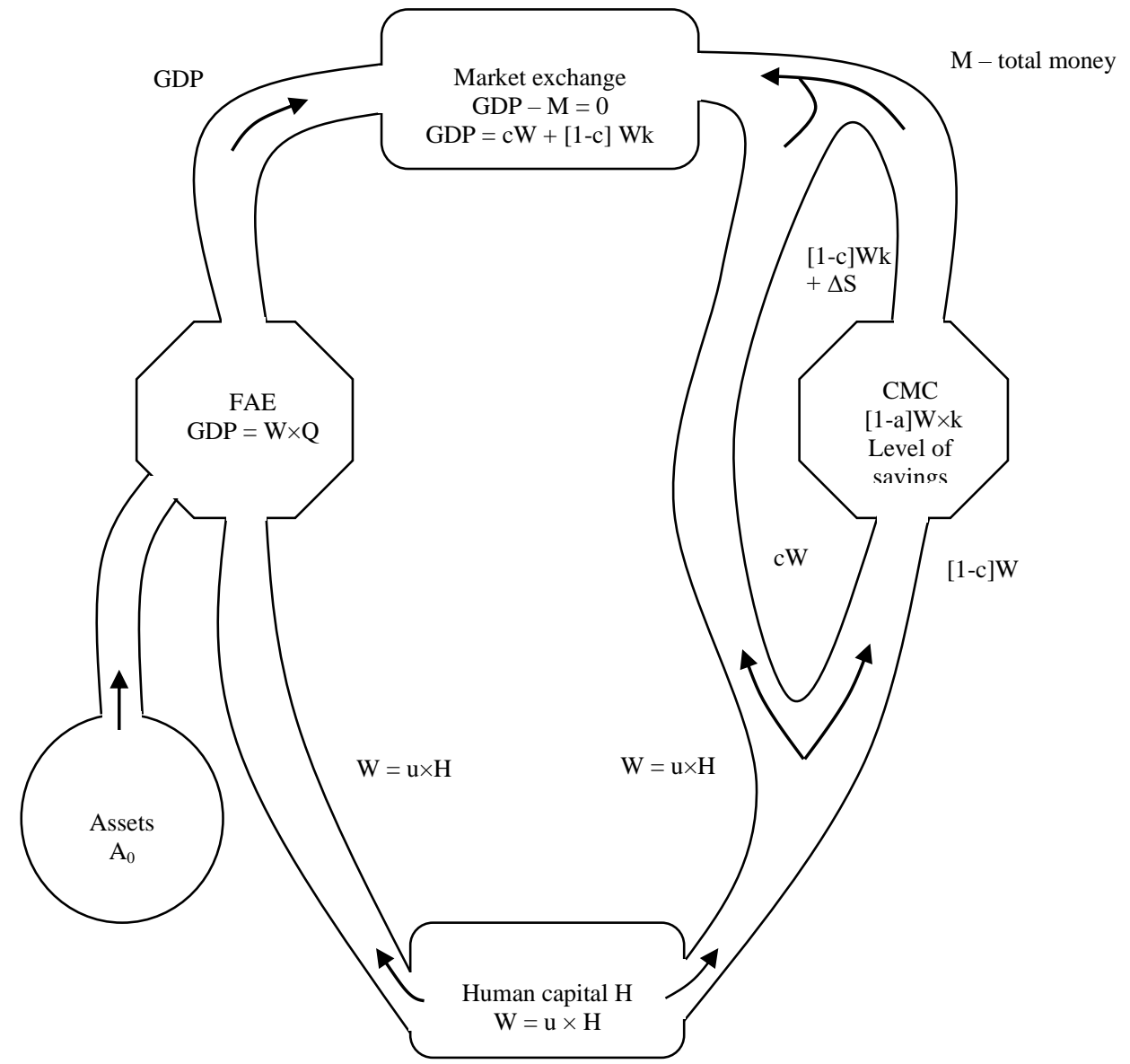

Fig. 2: The Market as A Mechanism for Equalizing the Value of Product and Money Flows.Source: [Dobija, 2007, 2011].

The quantities appearing in the scheme 2 have the following meaning: $\mathrm{W}$ - total wages and salaries, $\mathrm{H}$ - human capital of working people, $\mathrm{u}$ - percentage rate of paid labor, A - assets at book value, $\mathrm{c}$ - rate that separates the stream of labor claims [c < 1], FAE - function of economic activity, CMC - function of money creation through credit, S - level of savings [including pension funds], $\mathrm{k}$ - rate that increases the stream of $[1-\mathrm{c}] \mathrm{W}$ by credit action, $\mathrm{M}$ - total amount of money.

Here it is important to note that the stream that creates GDP is subject to influences of nature that significantly increase the value of products. This kind of influence is not present in the stream of labor costs, and in practice there is even an important element that reduces the intensity of this stream. These are taxes on wages, which must reduce the sum of money and threaten deflation. For these two reasons a credit is needed, the size of which can be estimated from the equation of exchange. But taxation of decent wages must be abandoned, since labor finances itself. The existing state of affairs is the main reason for the appearance of budget deficits. Respect for the system of economic concepts established by thermodynamics excludes the budget deficit as a permanent element of the economic system. 
With the accepted designations and additional ones, such as: $\mathrm{i}$ - inflation rate, $\Delta \mathrm{S}$ - change in savings balances, the exchange equation has the form (GDPR stands for real GDP):

$\mathrm{GDP}=\mathrm{GDPR}[1+\mathrm{i}]=\mathrm{c} \times \mathrm{W}+[1-\mathrm{c}] \times \mathrm{W} \times \mathrm{k}+\Delta \mathrm{S}$

If one assumes the condition $\mathrm{i}=0$, which means both no inflation and no deflation, the resulting equation is:

$\mathrm{GDP}=\mathrm{GDPR}=\mathrm{c} \times \mathrm{W}+[1-\mathrm{c}] \times \mathrm{W} \times \mathrm{k}+\Delta \mathrm{S}$

Dividing equation (15) by $\mathrm{W}$ in turn yields the formula (16):

$\mathrm{Q}=\mathrm{Q}_{\mathrm{r}}=\mathrm{c}+[1-\mathrm{c}] \times \mathrm{k}+\mathrm{d}$, where $\mathrm{d}=\Delta \mathrm{S} / \mathrm{W}$

The interpretation is clear. An essential condition for a good economy is the equality of nominal and real labor productivity. From formula (16) one also obtains the determination of the credit creation rate as follows:

$\mathrm{k}=\left[\mathrm{Q}_{\mathrm{r}}-\mathrm{c}-\mathrm{d}\right] /[1-\mathrm{c}]$

In turn, the adequate level of credit for a given economy is determined by the formula:

Credit level $=[1-\mathrm{c}] \mathrm{W}\left[\mathrm{Q}_{\mathrm{r}}-\mathrm{c}-\mathrm{d}\right] /[1-\mathrm{c}]=\mathrm{W} \times\left[\mathrm{Q}_{\mathrm{r}}-\mathrm{c}-\mathrm{d}\right]$

Thus, the amounts of permissible, and necessary, credit are a function of the ratio of real labor productivity $\mathrm{Q}_{\mathrm{r}}$ and the wealth of citizens. Note that the formula (18) defines not only the maximum and permissible credit, but also the necessary and indispensable credit. Since the condition $\mathrm{i}=0$ is to be satisfied, there cannot be $\mathrm{i}<0$, nor $\mathrm{i}>0$. With a smaller value of granted credit, deflation can occur and with an excessive growth of wages and prices, i.e. a decreasing $\mathrm{Q}$ - inflation. This means, among other things, that manipulation of the interest rate to regulate the "quantity of money" is, according to this equation, unacceptable. The interest rate is anchored in the economic constant "a". The economy requires well-functioning management systems that keep real processes in a state of non-decreasing labor productivity as measured by Q.

The labor productivity index Q plays a significant role in economics. In addition to its role in the equation of exchange and in determining the level of credit, it extends knowledge of the labor share of GDP. This share, defined as the ratio of labor costs to nominal GDP, is the simple inverse of $\mathrm{Q}=\mathrm{GDP} / \mathrm{W}$. Identity (19) represent these relationships.

$G D P=G D P \frac{1}{Q}+G D P \frac{Q-1}{Q}=W+G D P_{A}$

As you can see, the higher the share of wages in GDP, the poorer the country is because there is a lack of wealth contained in assets. Rich countries have assets of high value (infrastructure, machinery and equipment, savings, possible credit) and they account for wealth and contribute to GDP.

\section{Conclusion}

Knowing and understanding the principles of thermodynamics realizes their fundamental and comprehensive importance for the development of knowledge about reality. Accounting theory and systems are closely related to practice and have the characteristics of natural sciences. Therefore, it is not surprising that the principle of dualism, fundamental to accounting, forces the application of the principles of thermodynamics to the correct interpretation of capital and labor. And this is the beginning of a conceptual revolution, leading to a new illumination of the essence of PG, the essence of which is the continuous exchange of products for money. For understandable reasons, the existence and development of human capital is an important part of economic science. In this area, the achievements of thermodynamics in its initial development of knowledge about the work of the heat engine, make a natural, positive contribution to economic science, because this knowledge applies directly to the human body. In doing so, the positive influence of the various abstract heat engines found in nature on economic processes is revealed. The result of this influence is the finding that the economy viewed as a game with Nature has a positive sum. This means that profits can be made in the economy. Empirical studies formulated with the new theory have revealed the existence of an economic constant that determines the potential growth of initial capital. This constant has the value $\mathrm{a}=0.08$ [1/year]. It is essential for theoretical considerations of profit, interest rate, discount rate and fair wages. With the discovery of the applicability of the principles of thermodynamics and the existence of the size of the constant, economic science can join the ranks of natural sciences.

\section{References}

[1] Adamczyk, A. (2008). Lectures and Animations in General Physics. Thermodynamics. http://www.if.pw.edu.pl/ anadam/WykLadyFO/FoWWW_27.html (access date: 03.10.2020).

[2] Atkins, P. (2005). Galileo's Finger - The Ten Great Ideas of Science, Polish ed., Oxford University Press

[3] Atkins, P. (2007). Four Laws that Drive the Universe, Oxford University Press, New York

[4] Barbour, J. (2019). The End of Time: The Next Revolution in Physics, Copernicus Center.

[5] Barrow, J.D. (2003). From Alpha to Omega, The Constant of Nature, Vintage Books, London.

[6] Bejan, A. Tsatsaronis, G. (2021). Purpose in Thermodynamics, Energies, 14, 408. https://doi.org/10.3390/en14020408.

[7] Bliss, Ch. (1975). Capital Theory and the Distribution of Income, Oxford: North-Holland.

[8] Bliss, Ch., Cohen, A.J., Harcourt, G.C. (Eds.) (2005). Capital Theory, Vol. 1-3. Bodmin, Cornwall: Edward Elgar Publishing Limited.

[9] Cieślak, I. (2006). Human capital as the basis for managing labor costs in an enterprise, doctoral dissertation, Koźminsky University, Warsaw.

[10] Cieslak, I. (2008). Value of Human Capital and Wage Disparities [w:] Górowski I. (ed.), General Accounting Theory Evolution and Design for Efficiency, ss.289-303, Warszawa, WYDAWNICTWA AKADEMICKIE I PROFESJONALNE. 
[11] Cohen, A.J., Harcourt, G.C. (2005). Introduction. Capital Theory Controversy, [in:] Ch. Bliss, Cohen A.J., Harcourt G.C. (ed.), vol. I, Edward Elgar Publishing Limited, Northampton, Massachusetts.

[12] Cost of living in USA. https://www.expatistan.com/cost-of-living (dostęp: 10.10.2020).

[13] Dewdney, A.K. (2004). Granice rozumu, Wydawnictwo Amber.

[14] Dobija, M. (1998). How to Place Human Resources into the Balance Sheet, Journal of Human Resource Costing \& Accounting, Vol. 3, No 1, Spring https://doi.org/10.1108/eb029044.

[15] Dobija, M. (2004). "Theories of Chemistry and Physics Applied to Developing an Economic Theory of Intellectual Capital”, in: Knowledge Café for Intellectual Entrepreneurship Through or Against Institutions, Wydawnictwo WSPiZ im. Leona Koźmińskiego, Warszawa.

[16] Dobija, M. (2005). "Capital and Discount Rates in the Context of Thermodynamic Entropy”, Argumenta Oeconomica Cracoviensia, No. 3

[17] Dobija, M. (2007). Abstract Nature of Capital and Money, w: Cornwall L. M. New Developments in Banking and Finance, Nova Science Publishers, Inc., New York, s. 89-114

[18] Dobija, M. (2011a). Abstract Nature of Money and the Modern Equation of Exchange, Modern Economy, Vol. 2, No. 2. 142-152. https://doi.org/10.4236/me.2011.22019.

[19] Dobija, M. (2011b). Labor Productivity vs. Minimum Wage Level, Modern Economy, Vol.2, No 2, 780-787. https://doi.org/10.4236/me.2011.25086.

[20] Dobija, M. (2015). Economics approaches the fork in the road. Labor self-financing and tax free compensations or toil of deficit and deflation, International Journal of Accounting and Economics Studies, June 2015, https://doi.org/10.14419/ijaes.v3i2.4290.

[21] Dobija, M., Jędrzejczyk, M. (2013). Production Function in the Cost Accounting Approach and Managerial Applications, Zeszyty Teoretyczne Rachunkowości, 72, nr 128, s. 49-62. https://doi.org/10.5604/16414381.1063611.

[22] Dobija, M., Kurek, B. (2013a). "Towards Scientific Economics”, Modern Economy, Vol. 4 No. 4, $2013, \quad$ pp. $293-304$. https://doi.org/10.4236/me.2013.44033.

[23] Dobija, M., Kurek, B. (2013b) Scientific Provenance of Accounting, International Journal of Accounting and Economics Studies, Vol. 1, nr 2 (2013), s. 16-24. https://doi.org/10.14419/ijaes.v1i2.1054.

[24] Dobija, M., Renkas. J. (2020). Accounting among the Natural Sciences. Modern Economy, vol. 11, pp. 2081- 2100. https://doi.org/10.4236/me.2020.1112138.

[25] Dobija, M., Renkas. J. (2021). The thermodynamic principles as the theoretical basis of fair remuneration, International Journal of Physical Research, vol. 9(1), pp. 1-6, 2021. https://doi.org/10.14419/ijpr.v9i1.31247.

[26] Goetzmann, W.N., \& Ibbotson, R.G. (2006). History and the Equity Risk Premium, [in:] Goetzmann W.N., Ibbotson R.G. (ed.), The Equity Risk Premium: Essays and Explorations, Yale School of Management, Oxford University Press.

[27] Knight, F.H. [1921], Risk, Uncertainty, and Profit, Library of Economics and Liberty. Retrieved April 04, 2021 from: http://www.econlib.org/library/Knight/knRUP7.html,

[28] Kozioł, W. (2011). Stała potencjalnego wzrostu w rachunku kapitału ludzkiego, Nierówności Społeczne w Wzrost Gospodarczy, Uniwersytet Rzeszowski, Zeszyt nr 19, s. 252-260.

[29] Kozioł, W. (2014). Rozwój teorii pomiaru kapitału ludzkiego i godziwych wynagrodzeń, [w:] Dobija, M. (red.) Teoria rachunkowości. Podstawa nauk ekonomicznych (s. 156-193), Wydawnictwo Uniwersytetu Ekonomicznego w Krakowie, Kraków.

[30] Kurek, B. (2004). Rachunkowość jako stymulator rozwoju kultury, Zeszyty Teoretyczne Rachunkowości, Tom 24 (80), s. 38-59.

[31] Kurek, B. (2011). Hipoteza deterministycznej premii za ryzyko, Monografie: Prace doktorskie Nr 10, Uniwersytet Ekonomiczny w Krakowie, Kraków.

[32] Kurek, B. (2012). An Estimation of the Capital Growth Rate in Business Activities. Modern Economy, Vol. 3, nr 4, 364-372. https://doi.org/10.4236/me.2012.34047.

[33] Kurek, B., Górowski, I. (2020). Gender and Age as Determinants of Expected Rate of Return on Human Capital, „Central European Management Journal" Vol. 28, No. 4/2020, p. 30-50, ISSN https://doi.org/10.7206/cemj.2658-0845.33.

[34] Lambert, F.L. (2000). Disorder - A cracked crutch for supporting entropy discussion, The Journal of chemical Education, No 79(10) https://doi.org/10.1021/ed079p187.

[35] Oliwkiewicz, B. (2020). Oczekiwania płacowe a godziwe wynagrodzenia absolwentów studiów ekonomicznych [w:] Zarządzanie zrównoważonym rozwojem organizacji, (red.) D. Fatuła, Oficyna Wydawnicza AFM, Kraków, s. 67-94.

[36] Piketty, T. (2015). Kapitat w XXI wieku, Wydawnictwo Krytyki Politycznej, Warszawa.

[37] Pikulska-Robaszkiewicz, A. (1999). Lichwa w państwie i prawie republikańskiego Rzymu, Wydawnictwo Uniwersytetu Łódzkiego, Łódź.

[38] Pudlik, W. (2011). Termodynamika, Wydawnictwo Uniwersytet Gdański, Gdańsk.

[39] Renkas, J. (2012). Empiryczny test modelu kapitału ludzkiego i minimalnych wynagrodzeń, Nierówności Społeczne a Wzrost Gospodarczy, Zeszyt 24, ss. 180-191.

[40] Renkas, J. (2017a). Kapitał kreatywności - pomiar i wynagradzanie, Nierówności Społeczne a Wzrost Gospodarczy, Zeszyt nr 50, ss. 413-426. https://doi.org/10.15584/nsawg.2017.2.28.

[41] Renkas, J. (2017b). The tandem of "capital-work" as the basis for labor economics, International Journal of Accounting and Economics Studies, Vol 5, No 1 (2017), p. 26-32. https://doi.org/10.14419/ijaes.v5i1.7195.

[42] Schrödinger, E. (1998). Czym jest życie? Fizyczne aspekty żywej komórki. Umyst i materia. Szkice autobiograficzne, Warszawa: Prószyński i S-ka.

[43] Tobby, J., Cosmides, L., Barrett, H.C. (2003). Psychological Bulletin, The Second Law of Thermodynamics Is the First Law of Psychology: Evolutionary Developmental Psychology and the Theory of Tandem, Coordinated Inheritances: Comment on Lickliter and Honeycutt, No 6, p. 858-865. https://doi.org/10.1037/0033-2909.129.6.858. 